\title{
NOV ZAKON O SPODBUJANJU SKLADNEGA REGIONALNEGA RAZVOJA - NOVO OBDOBJE SLOVENSKE REGIONALNE POLITIKE
}

Spodbujanje skladne(jše)ga regionalnega razvoja v Sloveniji ima že dolgo tradicijo. Njegovi začetki segajo v leto 1971, ko je bil sprejet prvi pravni akt, ki je določal naloge s področja regionalne politike. Proces planiranja zahteva nenehno spremljanje stanja in prilagajanje novih izzivom, zato je bil sistem regionalne politike večkrat dopolnjen ali spremenjen. Zadnja večja sprememba se je zgodila leta 1999, ko je spodbujanje razvoja demografsko ogroženih območij zamenjal Zakon o spodbujanju skladnega regionalnega razvoja (Uradni list RS, št. 60/99 in 56/03). V zadnjem času je bil močno kritiziran, predvsem njegova določila o organizaciji in izvajanju regionalne strukture politike ter neustrezna določitev prednostnih območij delovanja regionalne politike. $\mathrm{V}$ praksi so se pojavljale številne operativne in konceptualne težave, zato je bil ob sklepanju prvega programskega obdobja in pred začetkom naslednjega, ki bo trajal od leta 2007 do leta 2013, pripravljen nov predlog. Njegov namen je je učinkovitejše odpravljanje regionalnih razvojnih razlik ter dopolnitev sistemskih podlag za doseganje skladnejšega regionalnega razvoja. Vlada Republike Slovenije je 23. junija 2005 nov Predlog zakona o spodbujanju skladnega regionalnega razvoja posredovala v sprejem Državnemu zboru, ki naj bi ga obravnaval na izredni seji v drugi polovici meseca julija 2005.

Predlog zakona o spodbujanju skladnega regionalnega razvoja je na prvi pogled podoben sedaj veljavnemu zakonu, saj sledi njegovi strukturi poglavij. V splošnih določbah so navedeni cilji in načela spodbujanja skladnega regionalnega razvoja ter opredeljene razvojne regije in kohezijski regiji. V nadaljevanju so opredeljeni temeljni programski dokumenti (Strategija regionalnega razvoja Slovenije, Državni razvojni program, programski dokumenti za Evropsko unijo, regionalni razvojni program, območni razvojni program), nosilci regionalne politike, državne spodbude za skladni regionalni razvoj, postopek za izvajanje projektnega financiranja ter prehodne in končne določbe.

Podrobnejši pregled gradiva razkrije, da so vsi deli zakona temeljito dopolnjeni ali pa spremenjeni. Število predlaganih dopolnitev členov veljavnega zakona in število novih členov je tolikšno, da ni bilo mogoče sprejeti le popravkov zakona, ampak je zato predlagan nov zakon. Cilji zakona so razširjeni. Sedaj se nanašajo na širšo opredelitev termina policentričnosti. Dodan je cilj ustvarjanja gospodarske osnove za razvoj obeh avtohtonih narodnih manjšin in romske skupnosti v Sloveniji ter spodbujanja gospodarskega sodelovanja z zamejskimi Slovenci in Slovenci po svetu. Predlog zakona ohranja načela regionalne politike iz dosedanjega zakona in dodaja nekatera nova. Načelo celovitosti izvajanja regionalne politike dopolnjuje tako, da je politika spodbujanja skladnega regionalnega razvoja obveznost nosilcev odločanja na vseh ravneh odločanja. To načelo je dopolnjeno z načelom čezmejnega delovanja regionalne politike.

Spremenjen je tudi prostorski okvir izvajanja regionalne politike. Vpeljane so razvojne regije, ki so prostorsko identične statističnim regijam na SKTE 3 ravni. V njih se bodo pripravljali regionalni razvojni programi, ki bodo sestavljeni iz strateškega in programskega dela. Slednji bo vseboval časovno in finančno ovrednotene razvojne programe. Regionalni 
razvojni programi bodo vsebovali območne razvojne programe, ki jih bodo pripravile občine vključene v območno razvojno partnerstvo. Območni razvojni program se lahko pripravi tudi za zavarovano območje in območja v prestrukturiranju, lahko pa zajema občine iz dveh ali več razvojnih regij. Novost sta kohezijski regiji. Vzhodna in južna ter Zahodna in severna Slovenija naj bi služili izvajanju kohezijske politike Evropske unije v Sloveniji. Za razvojne regije se sedaj obvezno pripravi regionalna zasnova prostorskega razvoja.

Slika 1: Predlagane razvojne regije in kohezijski regiji.

Figure 1: Development and cohesion regions in Slovenia according to the proposed Balanced Regional Development Act.

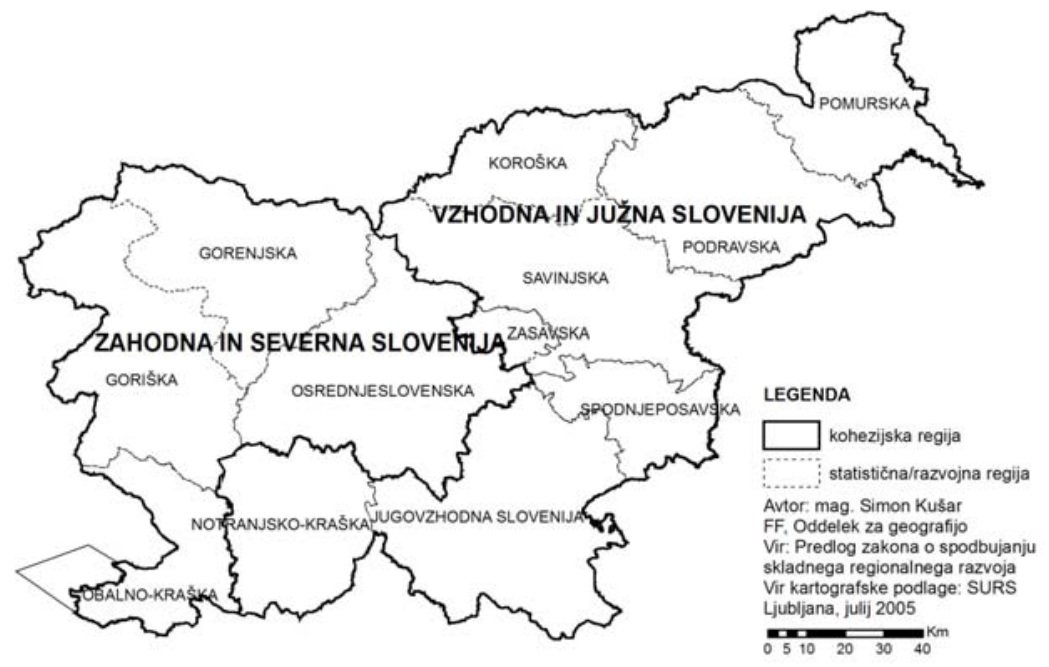

Vir: Predlog zakona o spodbujanju skladnega regionalnega razvoja. 23. junij 2005. Ljubljana, 48 str. Medmrežje URL: http://www.gov.si/svrp/5novo/1n-231.html (12. julij 2005).

Največjih sprememb je bila deležna organizacija spodbujanja skladnega regionalnega razvoja oziroma njeni nosilci. V vsaki razvojni regiji se bo ustanovila zveza občin. Njene naloge bodo sprejem regionalnega razvojnega programa ter potrjevanje izvedbenega načrta regionalnega razvojnega programa. Organ odločanja zveze je svet regije. Zveza občin ustanovi regionalni razvojni svet, ki bo imel naslednje naloge: sprejemanje sklepov o pripravi regionalnega razvojnega programa ter drugih odločitev v postopku njegove priprave, priprava predloga izvedbenega načrta regionalnega razvojnega programa, spremljanje in vrednotenje regionalnega razvojnega programa, imenovanje predstavnikov v razvojni svet kohezijske regije, sodelovanje v programskih svetih za pripravo regionalnih zasnov prostorskega razvoja na območju razvojne regije, imenovanje vodij odborov sveta, obravnaval pa bo tudi druge zadeve regionalnega pomena. Regionalne razvojne agencije bodo še naprej zadolžene za pripravo regionalnega razvojnega programa, pripravo izvedbenega načrta regionalnega razvojnega programa in za pomoč pri pripravi regionalnih projektov. Regionalne razvojne 
agencije bodo služile tudi kot tehnična, strokovna in administrativna podpora delovanju zveze in sveta.

Regionalne spodbude se bodo dodeljevale vsem razvojnim regijam. Kot prednostna območja so opredeljena »prednostna območja«, ki bodo natančneje določena v Strategiji regionalnega razvoja Slovenije. Z njimi so mišljena območja znotraj razvojnih regij, ki najbolj zaostajajo v razvoju oziroma se soočajo $\mathrm{z}$ velikimi strukturnimi problemi. V njih se bodo izvajali posebni ukrepi regionalne politike, pri prednostnem dodeljevanju spodbud pa jih bodo morali upoštevati vsi proračunski uporabniki.

$\mathrm{V}$ predlogu zakona o spodbujanju skladnega regionalnega razvoja je obsežno poglavje namenjeno postopku za izvajanje projetnega financiranja.

Glede na časovne obveze iz predloga zakona lahko v kratkem pričakujemo ustrezne podzakonske akte, ki bodo omogočili, da se bodo začeli formirati sveti regij in regionalni razvojni sveti ter pripravljati regionalni razvojni programi. Še prej pa mora biti zakon sprejet v Državnem zboru. Obeta se torej pestro obdobje intenzivnega dela na področju regionalnega planiranja.

Vir: Predlog zakona o spodbujanju skladnega regionalnega razvoja. 23. junij 2005. Ljubljana, 48 str. Medmrežje, URL: http://www.gov.si/svrp/5novo/1n-231.html (12. julij 2005).

Simon Kušar 